\title{
Review of Chudinov A.P., Budaev E.V., Solopova O.A. 2020. Political Metaphorology: A Discursive Turn. Moscow: Flinta. 234 p. ISBN 978-5-9765-4326-3 \\ Vladimir I. KARASIK \\ Pushkin State Russian Language Institute Moscow, Russia
}

For citation:

Karasik, Vladimir I. 2020. Review of Chudinov A.P., Budaev E.V., Solopova O.A. 2020. Political Metaphorology: A Discursive Turn. Moscow: Flinta. 234 p. ISBN 978-5-9765-4326-3. Russian Journal of Linguistics 25 (1). 284-290DOI: 10.22363/2687-0088-2021-25-1-284-290

\section{Рецензия на книгу:}

Чудинов А.П., Будаев Э.В., Солопова О.А.

Политическая метафорология:

Дискурсивный поворот.

\section{М.: Флинта, 2020. 234 с. ISBN 978-5-9765-4326-3}

\section{В.И. КАРАСИК}

Государственный институт русского языка имени А.С. Пушкина Москва, Россия

\section{Для цитирования:}

Карасик В.И. Рецензия на книгу: Чудинов А.П., Будаев Э.В., Солопова О.А. Политическая метафорология: Дискурсивный поворот. М.: Флинта, 2020. 234 с. ISBN 978-5-97654326-3. Russian Journal of Linguistics. 2021. T. 25. № 1. C. 284-290. DOI: 10.22363/26870088-2021-25-1-284-290

Рецензируемая книга известных российских исследователей, давно и плодотворно изучающих проблемы политической и когнитивной лингвистики (Будаев 2011, Будаев, Чудинов 2006, 2008, Солопова 2013, 2015, Солопова, Чудинов 2018, Чудинов 2001, 2013, 2012), представляет собой развитие их оригинальной теории политической метафоры. Авторы опираются на классический труд Дж. Лакоффа и М. Джонсона (2004) и признают, что в 
настоящее время в когнитивной лингвистике «заметно все возрастающее обращение к методам и эвристикам дискурс-анализа, критического анализа дискурса, теории дискурса, герменевтического анализа дискурса и другим дискурсивно ориентированным направлениям» (с. 4). Детальный анализ дискурсивного поворота в современной политической лингвистике и составляет предмет изучения в рассматриваемой книге.

Во введении к монографии отмечено, что в настоящее время выделяются пять основных направлений в изучении политического дискурса российскими лингвистами: 1) национальный политический дискурс; 2) политический дискурс определенной эпохи; 3) дискурс определенного политического события; 4) дискурс политической партии (движения); 5) личностный дискурс политика.

Книга состоит из трех глав, посвященных соответственно дискуссионным проблемам политической метафорологии, сопоставительной политической метафорологии и ее исторической динамике.

Первая глава посвящена определению статуса политической лингвистики, характеристикам политической метафорологии, когнитивным, риторическим и семантико-стилистическим истокам теории концептуальной метафоры, методикам ее когнитивного анализа и характеристике дискурсивного поворота в этой области знания.

Анализ множества публикаций, выполненных в рамках политической лингвистики, позволяет, как отмечают авторы, утверждать, что в настоящее время можно выделить три основных понимания статуса этого объекта лингвистических исследований: это новая междисциплинарная наука, объединяющая лингвистику и политологию, либо раздел лингвистики, в котором рассматриваются характеристики политической коммуникации (наряду с юридической лингвистикой, медиалингвистикой, этнолингвистикой и др.), либо частное направление функциональной стилистики. Первое и второе направления доминируют, и можно отметить, что значимые акценты в понимании статуса этой науки зависят от базовых установок исследователей, которые квалифицируют себя в качестве лингвистов либо политологов. Аналогичное положение дел, скажем, имеет место в противопоставлении социолингвистики и социологии языка. Сложность и многоплановость решаемых проблем отражается в новом науковедческом понятии «федерация когнитивных наук». Можно согласиться с А.П. Чудиновым в том, что в научном сообществе не подвергаются сомнению теоретические основания гибридных научных направлений, возникших на пересечении фундаментальных научных дисциплин, таких, как психолингвистика или социолингвистика, но меньше повезло тем областям знания, которые выделяются на основе специфического предмета исследования (сферы коммуникации), это юрислингвистика и медиалингвистика. Важным аргументом в обосновании статуса той или иной области знания является набор используемых 
в ней исследовательских методик. В политической лингвистике успешно используются когнитивные, дискурсивные, лингвокультурологические, психолингвистические, корпусно-статистические методики, а также методики общественных наук. Говоря об интенсивном развитии когнитивной лингвистики в нашей стране, А.П. Чудинов перечисляет следующие научные школы, не имеющие аналогов за рубежом: лингвокультурология, лингвоконцептология, теория прецедентных феноменов, сопоставительная и историческая метафорология, когнитивная лингвоперсонология, когнитивная лингвоаксиология, когнитивная лингвосемиотика и когнитивная теория креолизованного текста (с. 20).

Заслуживает внимания изложенный в книге информативный обзор источников теории концептуальной метафоры. Западные когнитивисты доказали, что метафора как когнитивный механизм не ограничивается сферой языка, но проявляется в мышлении и в действии. Достижения отечественных ученых в этом плане вносят вклад в развитие когнитивной метафорологии с учетом изучения языка и стиля известных политиков, а также исследований, посвященных ораторскому искусству.

Специалисты несомненно обратят внимание на анализируемые в книге методики когнитивного анализа политических метафор. Рассматриваются метафоры, объединяемые сферой-источником метафорической экспансии, сферой-мишенью, единичные концептуальные метафоры, метафоры субъекта политического дискурса, метафоры в политическом нарративе, модели концептуальной интеграции. Отмечено, что библиография только метафорологических когнитивных исследований насчитывает более тысячи публикаций.

Одним из ярких индикаторов современной коммуникативной среды является широкое распространение сетевого дискурса. Авторы справедливо отмечают, что «важным фактором дискурсивного поворота в риторическом направлении стало активное развитие интернет-технологий, которые сформировали новую коммуникативную реальность, что неизбежно отразилось на закономерностях функционирования политической коммуникации. Современные исследователи сходятся во мнении, что важнейшим источником распространения политической информации стали социальные сети, блоги, форумы и иные формы интернет-коммуникации, которые оказывают все большее влияние на традиционные СМИ, которые, в свою очередь, также активно эксплуатируют возможности всемирной паутины для распространения информации в обществе» (с. 44-45). Признавая несомненные достижения западных исследователей, которые внесли большой вклад в развитие когнитивной лингвистики, авторы подчеркивают, что в российской когнитивистике были высказаны важные идеи относительно необходимости интегративных когнитивно-дискурсивных исследований, особенно значимы в этом плане работы В.3. Демьянкова (Демьянков 1992) и Е.С. Кубряковой (Кубрякова 2004). 
Во второй главе книги рассматриваются проблемы метафорической когниции в контексте культуры, теории и практики сопоставительной политической метафорологии и сопоставительного анализа метафор в современном политическом дискурсе.

Заслуживает внимания обоснованный в монографии тезис о значительном сходстве концептуальных метафор в западных и восточных лингвокультурах. Вместе с тем существуют и определенные отличия: так, «китайские метафоры со сферой-источником «Семья» отражают национальную специфику заключения брака. В китайском представлении браку предшествует не столько знакомство и ухаживание, сколько сложные переговоры, направленные на защиту интересов будущих супругов и их родственников. Это сближает рассматриваемые образы с метафорами торговой сделки, имеющей важное моральное основание: брак рассматривается китайцами как выполнение обязательств перед предками» (с. 50). Очень важным является положение о том, что при межкультурном сопоставлении важно разграничивать окказиональные метафоры и доминантные метафорические модели (термин А.П. Чудинова). Интересны приведенные в книге конкретные наблюдения применительно к разным типам концептуальных метафор, установленные учениками А.П. Чудинова в их диссертационных исследованиях на материале шоу-дискурса, экологического дискурса и дискурса феминисток.

В монографии выделены следующие перспективные направления сопоставительной концептуальной метафорологии:

1. Сопоставление доминантных метафор различных эпох.

2. Сопоставление метафорических периодов бурь и метафорических штилей.

3. Сопоставление метафорического репертуара политических партий в различных политических условиях (ср.: правящая партия / партия в условиях парламентской оппозиции / партия во внесистемной оппозиции.

4. Сопоставление метафорического репертуара различных политиков, а также одного из политиков на различных этапах его деятельности (с. 60).

Лингвисты и политологи несомненно обратят внимание на существенное различие в использовании метафорических моделей, используемых в предвыборном дискурсе в России и Великобритании. Так, в работе О.А. Солоповой показано, что общими метафорическими моделями в сравниваемых лингвокультурах являются следующие: «Жизнь - это война» и «Страна - это больной организм», вместе с тем в российском политическом дискурсе востребованной оказалась метафорическая модель «Страна - это мир преступности», а в британском - «Жизнь - это театр» (с. 63).

Сопоставительные исследования политической метафоры по определению являются дискурсивными, и используемые в них методики дают возможность, как отмечают авторы, объединить их в следующие группы: «1) межкультурное сопоставление, направленное на поиск универсального 
и культурно-специфического в политических метафорах разных этнокультурных сообществ; 2) идеологическое сопоставление, направленное на изучение метафор, характерных для сторонников разных идеологических взглядов, приверженцев различных методов решения определенных политических проблем, участников определенных политических объединений; 3 ) идиолектное сопоставление, направленное на изучение метафор определенных политиков, а также других личностей как субъектов дискурсивной деятельности; 4) гендерное сопоставление, связанное с исследованием как гендерных предпочтений в выборе метафор при построении политического дискурса, так и в сопоставлении способов метафорической концептуализации политиковмужчин и политиков-женщин; 5) диахроническое сопоставление метафор, охватывающее вопросы исторического развития политического дискурса; 6) мультимодальное сопоставление, предметом которого являются семиотические закономерности функционирования метафор в невербальной политической коммуникации и ее взаимосвязи с вербальной коммуникацией» (с. 66).

Предметом детального описания в третьей главе монографии являются характеристики диахронической метафорологии, лингвопрогнозные сценарии, системы метафорических моделей в политическом дискурсе России, США и Великобритании.

Методологически важен тезис, обоснованный О.А. Солоповой: «нельзя пытаться понять метафору дискретно: только через лингвистическую, когнитивную или социальнокультурную составляющую. Поскольку язык, мышление и культура неразрывно связаны, дискурсивные метафоры социально и культурно ситуативны, зависимы от контекста, дву- и многосмысленны: предлагают возможности для разнообразных интерпретаций» (с. 127). Такая взаимосвязь иллюстрирует дискурсивную сущность политических концептуальных метафор. Принципиально важным является также положение о том, что «исследование политической метафорики с учетом исторической перспективы подтверждает постоянное взаимодействие двух свойств системы политических метафор: архетипичности и вариативности. Развитие системы политических метафор, как правило, проявляется не в появлении принципиально новых смысловых типов метафор, а в динамике уровня метафоричности политического дискурса, в изменении частотности использования тех или иных метафорических моделей, в создании новых метафорических наименований на основе традиционных моделей, в расширении сфер-мишеней метафорической экспансии, когда для обозначения социально актуальных феноменов создаются все новые и новые метафорические обозначения» (с. 140). Эти выводы бесспорно должны быть приняты к сведению исследователями не только политического дискурса, но и других типов общения.

В заключении авторы констатируют, что «соотнесение получаемых знаний с социальными ценностями и целями - важная черта, привнесенная дискурсивным подходом в метафорологию» (с. 201). 
Подводя итоги, считаю необходимым подчеркнуть, что выход в свет рецензируемой книги стал заметным событием в развитии когнитивной лингвистики, органически включающей дискурсивный анализ социальных и коммуникативных явлений.

(C) Vladimir I. Karasik, 2021

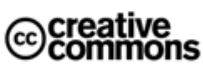

This work is licensed under a Creative Commons Attribution 4.0 International License https://creativecommons.org/licenses/by/4.0/

\section{СПИСОК ЛИТЕРАТУРЫ / REFERENCES}

Будаев Э.В. Сопоставительная политическая метафорология. Нижний Тагил: НТГСПА, 2011. [Budaev, Eduard V. 2011. Sopostavitel'naya politicheskaya metaforologiya (Comparative political metaphorology). Nizhny Tagil: NTGSPA Publ.].

Будаев Э.В., Чудинов А.П. Метафора в политическом интердискурсе. Монография. Екатеринбург: Урал. гос. пед. ун-т, 2006. [Budaev, Eduard V. \& Anatoly P. Chudinov. 2006. Metafora $v$ politicheskom interdiskurse. (Metaphor in political interdiscourse). Yekaterinburg: Ural state pedagogical university Publ.].

Будаев Э.В., Чудинов А.П. Метафора в политической коммуникации. М.: ФЛИНТА: Наука, 2008. [Budaev, Eduard V. \& Anatoly P. Chudinov. 2008. Metafora v politicheskoy kommunikatsii. (Metaphor in political communication). Moscow.: Flinta: Science Publ.].

Демьянков В.3. Когнитивизм, когниция, язык и лингвистическая теория // Язык и структуры представления знаний в языке. М.: ИНИОН РАН, 1992. С. 39-77. [Demyankov, Valery Z. 1992. Kognitivizm, kognitsiya, yazyk i lingvisticheskaya teoriya. (Cognitivism, cognition, language and linguistic theory) Language and Structures of Knowledge Representation in Language. 39-77.].

Кубрякова Е.С. Об установках когнитивной науки и актуальных проблемах когнитивной лингвистики // Известия РАН. Сер. литературы и языка. 2004. Т. 63. № 3. С. 3-12. [Kubryakova, Elena S. 2004. Ob ustanovkakh kognitivnoy nauki i aktual'nykh problemakh kognitivnoy lingvistiki (On the attitudes of cognitive science and current problems of cognitive linguistics) The Bulletin of the Russian Academy of Sciences: Studies in Literature and Language 63 (3). 3-12.].

Лакофф Д., Джонсон М. Метафоры, которыми Мы Живём. Москва: Едиториал УРСС, 2004. [Lakoff, George \& Mark Johnson. 2004. Metaphors We Live By. Moscow: URSS.].

Солопова О.А. Когнитивно-дискурсивная ретроспекция: исследование моделей будущего в политическом дискурсе: монография. Челябинск: Изд. центр ЮУрГУ, 2013. [Solopova, Olga A. 2013. Kognitivno-diskursivnaya retrospektsiya: issledovaniye modeley budushchego $\mathrm{v}$ politicheskom diskurse: monografiya (Cognitive-discursive retrospection: a study of models of the future in political discourse). Chelyabinsk: Ed. center of SUSU Publ.].

Солопова О.А. Диахроническая сопоставительная метафорология: исследование моделей будущего в политическом дискурсе: монография. М.: ФЛИНТА: Наука, 2015. [Solopova, Olga A. 2015. Diakhronicheskaya sopostavitel'naya metaforologiya: issledovaniye modeley budushchego v politicheskom diskurse: monografiya (Diachronic comparative metaphorology: a study of models of the future in political discourse: monograph). Moscow: Flint: Science Publ.]. 
Солопова О.А. Чудинов А.П. Диахронический анализ метафор в британском корпусе текстов: колокола победы и Russia's V-Day // Russian Journal of Linguistics. 2018. T. 22. № 2. C. 313-337. [Solopova, Olga A. \& Anatoly P. Chudinov. 2018. Diachronic Analysis of Political Metaphors in the British Corpus: from Victory Bells to Russia's VDay. Russian Journal of Linguistics 22 (2). 331-317] DOI: 10.22363/2312-9182-2018313-337

Чудинов А.П. Россия в метафорическом зеркале: когнитивное исследование политической метафоры (1991-2000): Монография. 2001. [Chudinov, Anatoly P. 2001. Rossiya v metaforicheskom zerkale: kognitivnoye issledovaniye politicheskoî metafory (1991-2000) (Russia in a Metaphorical Mirror: A Cognitive Study of Political Metaphor (1991-2000))].

Чудинов А.П. Метафорическая мозаика в современной политической коммуникации: монография. 2003. [Chudinov, Anatoly P. 2003. Metaforicheskaya mozaika v sovremennoy politicheskoy kommunikatsii: monografiya. (Metaphorical mosaic in modern political communication: monograph)].

Чудинов А.П. Политическая лингвистика. 2012. [Chudinov, Anatoly P. 2012. Politicheskaya lingvistika (Political linguistics)].

\section{Book review history:}

Received: 4 December 2020

Accepted: 21 January 2021

\section{История рецензии:}

Дата поступления в редакцию: 4 декабря 2020

Дата принятия к печати: 21 января 2021

\section{Bionote:}

Vladimir I. KARASIK is Doctor habil., Professor in the Department of General and Russian Linguistics at Pushkin State Russian Language Institute (Moscow, Russia), and Professor at Tianjin Foreign Studies University (Tianjin, China). His research interests embrace sociolinguistics, cultural linguistics, pragmatics and discourse analysis.

\section{Contact information:}

Pushkin State Russian Language Institute

Academic Volgin Str., 6, Moscow, 117485

e-mail: vkarasik@yandex.ru

ORCID: 0000-0001-8306-5317

\section{Сведения об авторе:}

Владимир Ильич КАРАСИК - доктор филологических наук, профессор кафедры общего и русского языкознания Государственного института русского языка имени А.С. Пушкина; профессор Тяньцзиньского университета иностранных языков (КНР). Специалист в области социолингвистики, прагмалингвистики, лингвокультурологии, теории дискурса.

\section{Контактная информация:}

Государственный институт русского языка имени А. С. Пушкина

Россия, 117485, Москва, ул. Академика Волгина, д. 6

e-mail: vkarasik@yandex.ru

ORCID: 0000-0001-8306-5317 